\title{
Trade Unions and Climate Change: The Jobs versus Environment Dilemma ${ }^{1}$
}

Nora Räthzel (Umeå University, Sweden)

David Uzzell (university of Surrey, UK)

\section{Abstract}

Trade unions are actively engaging with the climate change agenda and formulating climate change policies. Although governments are placing considerable effort on changing consumer behaviour, arguably the most significant impacts on climate change will be through changes in production. Even changes in consumption will have consequences for production. Changes in production will affect workers through the loss of jobs, the changing of jobs, and the creation of new jobs. The jobs versus environment dilemma is a significant issue affecting workers worldwide. In this paper we focus on the ways in which international trade unions are conceptualising the relationship between jobs and the environment, which provide the point of departure from which climate change policies can be formulated. Extended interviews were conducted with senior policy makers in national and international trade unions. On the basis of their responses, four discourses of trade union engagement with climate change are discussed: 'technological fix', 'social transformation', 'mutual interests' and 'social movement' discourses, which were theorised in the context of the different international histories and models of trade unionism. All discourses imply a reinvention of unions as social movements but do not see nature as a partner in human development.

\section{Keywords}

trade unions; climate change; environmental degradation; jobs versus environment; social movement unionism

\section{Introduction: Situating the question}

A dominant thrust of government activity to combat climate change has been to target consumption and the individual consumer (DEFRA, 2008). It has placed an emphasis on changing people's "insatiable appetites" through motivating or forcing them to change their behaviours. The fact that governments have contradictory policies, advocating sustainability and at the same time encouraging consumption in order to counter economic recession, is hidden by arguing that consumers should consume in a "sensible way". A more radical position suggests that we need to transform our ways of life and strive for 'prosperity without growth' as Jackson (2009) expresses it, or aim for the triple dividend: reducing unemployment, cutting carbon emissions, and providing people with an enhanced quality of life by reducing working hours - getting more from less (Schor, 2010).

Another approach shifts attention away from consumption to production and advocates reducing Greenhouse Gas emissions by developing more efficient technologies a 'have your cake and eat it' policy. This proposes that "ecological modernisation", through the development of new, so-called green technologies, will increase growth, while at the

\footnotetext{
${ }^{1}$ Published in Räthzel, N. and Uzzell, D. (2011) 'Trade Unions and Climate Change: The Jobs versus Environment Dilemma', Global Environmental Change, 21, 1215-1223
} 
same time have positive effects on the environment (for an account of such positions see: Redclift and Woodgate, 2005; Mol, Sonnenfeld and Spaargaren, 2009). Whether one subscribes to 'technological fixes' or more profound transformations, production and thus jobs will be affected. Even policies that centre predominantly on consumption will create less or changed demand and will influence production processes indirectly. This will affect workers through the loss of jobs, the changing of jobs, and the creation of new jobs, hopefully the so-called 'Green Jobs'.

Despite the inevitable impact of climate change and climate change measures on the production process and thus on work, research in this area is scarce. While there is considerable research on technological solutions and macro analyses of the consequences of environmental measures on employment, trade unions, as one of the principal social actors in the production process, have been largely ignored (but see: Labor Studies Journal 2011). Environmental studies have largely ignored labour issues, while labour studies have paid little attention to climate change issues.

The scarce research that has been undertaken on trade unions and environmental policies has focused on specific unions in specific countries. One of the first studies, reflecting the early engagement of the trade union movement in Australia with environmental issues, was on the environmental policies and activities of unions in the construction industry in the 1970's, referred to as the 'Green Bans' (Burgmann and Burgmann, 1998). More recent work has been undertaken in Australia (Snell and Fairbrother, 2011) and in the USA and Canada (Savage and Soron, 2011; Keil, 1994; Stevis 2011). Some projects have been undertaken by unions in Europe (Valenduc, 2001). While this work has been significant in drawing attention to the ways in which some trade unions in the Anglophone world have taken up climate change issues, there is still much to be known.

Trade Unions are typically represented as standing in the way of climate change measures. However, while trade unions might have been slow in placing climate change issues on their agenda, environmental movements have been slow to recognise the legitimacy of workers' interests in defending their jobs. This may be one of the reasons why there has been little cooperation between environmental movements and trade unions, although this is gradually changing (e.g., the Blue-Green Alliance brought together the US Steel Workers' Union and the Sierra Club in 2006). In the UK it would have been unimaginable 10 years ago for the Deputy General Secretary of the Trade Union Congress to stand up at a conference and declare to trade unionists and environmental NGOs sitting next to each other: "And welcome everyone to the TUC - where green runs alongside red as our colour of choice." (O'Grady, 2010)

Given the globalisation of Capital and the need for unions to organise internationally, our research has focussed on examining the climate change policies and positions of international union confederations and federations, and industrial unions in the countries of the Global South and North, whose production affects climate change specifically. We have focused on trade union officials who are responsible for developing the climate change policies of their respective unions. Given the short history of environmental policies in most unions and therefore the lack of knowledge about these issues, such key agents play an 
important role in creating and shaping these policies. In this paper we present four different discourses within international unions, aiming to reconcile the protection of jobs with the protection of the environment.

Before we present our results it will be useful to briefly discuss key concepts, which have framed investigations of the relationship between environmental regulations and employment, since these lie at the heart of trade union concerns.

\section{Environment and Employment - discussing macro-economics}

Two hypotheses have informed the debate concerning the impact of environmental legislation on competiveness and employment: the 'Porter hypothesis' and the 'Pollution Haven hypothesis'.

Industry tends to resist environmental regulations arguing that they impact negatively on competiveness and threaten jobs (Goodstein, 1999). The Porter Hypothesis (Porter and van der Linde, 1995) argues that, contrary to commonly held assumptions, stronger environmental regulations will have a minimal effect on competitiveness because they encourage innovation and efficiency, and may even lead to employment gains. The little research evidence there is would seem to suggest that the impact of environmental regulation on jobs is marginal, and in some cases may be positive (Morgenstern, Pizer and Jhih-Shyang, 2002; Bezdek, Wendling and DiPerna, 2008). The effects are influenced, however, by the scale at which the hypothesis is tested, i.e. the level of the firm, the nation or the sector (Wagner, 2004). Rennings, Ziegler and Zwick (2001) have found that while environmental product and service innovations increase the probability of creating jobs, "end-of-pipe eco-innovations [i.e. technology used to remove contaminants at the last stage of an industrial process, e.g. scrubbers on smokestacks] increase the risk of destroying jobs, however at a higher significance level." Moreover, they argue, environmental innovations "...are skill-biased, they have a significant impact on employment changes if they are substantial and if they are induced by regulations. Firms expecting increasing sales are more prone to increase employment, while firms that want to slash costs by innovation and compete by soft factors decrease employment more frequently." (p. 2). Another factor which may have led to a false support for the hypothesis, is that most studies have paid comparatively little attention to the competitiveness, employment consequences and environmental effects of environmental regulations in the context of relationships between the Global North and the Global South. We use the term 'North-South' as shorthand for the discrepancy between poorer and richer countries. This discrepancy is still relevant, even though some countries traditionally defined as part of the 'South' have come to play important roles in the global economy. (Silver 2003:10). Most studies have been carried out within the North where wage and cost as well as environmental regulation differentials are not so large. Taking North-South relations into account would necessitate consideration as to whether jobs are moved to the South as a result of environmental regulations in the North.

A second hypothesis that has a bearing on our work, namely the 'Pollution Haven hypothesis', argues that heavily polluting industries will migrate from developed economies with tough environmental legislation to less regulated and developed economies, thereby 
acquiring a comparative cost advantage (Wagner, 2004). Malm points out that the evidence of this is weak except for a few isolated examples because "the costs of complying with environmental regulations rarely form a significant factor when corporations make their investment decisions (or set their prices)" (2011, p7).

Considering the amount of literature and the high level reports (Pollin et. al. 2009, Neale 2010) suggesting a win-win situation for politics, industry, and the environment in a "green economy", the inevitable question is why have industries and governments been so reluctant to engage in a green transformation. Macro-level analyses cannot answer such a question because they do not take social actors, their interests and motivations into consideration. There is a gap between macro-economic analysis and workers' perceptions of the relationship between jobs and the environment. Predicting the employment potential of a green economy means little when companies argue that environmental regulations will force them to make workers redundant, when it is argued that relocation of production has been the result of environmental regulations or when part of the social representation of employment risk is located in the carbon emissions reductions discourse. Workers are more likely to be influenced by these arguments, which correspond to their lived reality, than by macro-economic models. A third of workers responding to a survey thought that their job was likely to be at risk as a consequence of tougher environmental regulations (Rosewicz, 1990). Such concerns become even more plausible for unionists, since workers in unionized workplaces are "disproportionately affected by production shifts [e.g., to China]" (Bronfenbrenner and Luce, 2004). Our research aims to close the gap between macroeconomic models and social actors' practices and interests by examining the ways in which unionists seek to solve what they perceive as a conflict between job creation and environmental protection.

The prospect of new green jobs in a low carbon economy constitutes a strong argument for international trade unions in their struggle to combat climate change (ITUC, 2011; UNEP, 2008; SustainLabour/ITUC, 2009). This does not mean, however, that a trade union in a specific plant at a specific moment will use such general arguments for its decisions. When a union is confronted with the alternative of agreeing to the construction of a coal-fired power station which will guarantee new jobs, or joining environmentalists in fighting against its construction in the name of a green future promising more green jobs under conditions that are yet to be realised, then such a union will be confronted with the harsh reality of the environment versus jobs dilemma. Examining the ways in which union officials conceptualise such a dilemma and seek strategies to reconcile workers' interests with environmental needs, is the aim of this paper.

The importance of unions as actors contributing to sustainable development was advocated almost twenty years ago in the Agenda 21 proposals from the 1992 Rio Earth Summit in a document on 'Strengthening the Role of Workers \& their Trade Unions' (United Nations, 2009). Reading it today, three features in particular are striking. First, environmental issues are often bound up with health and safety issues, an association that we have found in our research as well. Second, there is an emphasis on collaboration within a tripartite system of government, employers' and workers' organizations to encourage capacity building within unions in order to involve them in decision-making on the design, implementation, promotion and evaluation of programmes for sustainable development. 
Finally, it is advocated that unions should be involved in the development of improvements to both the work environment and the production process, as well as working within the local community.

Given this early initiative, it is surprising that it was not until 2006 that an international trade union conference on the environment involving more than 150 unions was held in Nairobi (UNEP, 2006). Not only did they discuss the significance of sustainable development for the trade union movement, but also agreed to incorporate environmental rights into their definition of traditional workers' rights. In 2009, the International Metalworkers Federation (IMF) organised an international conference to formulate their demands for an international agreement on climate change policies, and in 2010 the International Federation of Transport (ITF) workers dedicated one day of their three-day world conference to issues of climate change. And as part of COP 15 and 16 local and international unions organised workshops at the World of Work Pavilion (WOW) attended by more than 1000 participants, arguing it is no longer acceptable for unionists to ignore environmental concerns or "leave them to the environmentalists". Since 2009 the ITUC, along with other national and international unions, has a special website dedicated to climate change issues. Whether these activities translate into policies at national and local levels is a question that remains to be investigated. Nevertheless, trade unions have become social actors, whose positions towards climate change need to be taken into account by governments, business, and scholars.

\section{Methodology: Interviewing Trade Unions}

This paper presents results from a study investigating the ways in which trade unions in the Global North and the South are responding to the dual challenge of globalising work division and globalising environmental degradation. In this paper we focus on one aspect of these two challenges, namely the way in which international unions respond to the tension between the need to protect jobs and the need to protect the environment.

The methods employed were a desktop analysis of trade union policy statements and discussion papers, participant observation at conferences, and in-depth interviews with senior trade union officials and senior members of national and international organisations that interact with the trade union movement. Thirty-five interviews were conducted with union officials of national unions in Brazil, Malaysia, Singapore, South Africa, Spain, Sweden, and the UK, as well as with international federation officers of these unions in Brussels, Geneva, London and Paris. The interviews were conducted between March 2009 and December 2010 and lasted between 11/2 - 2 hours, some longer. They were recorded with the interviewees' agreement and then transcribed. Anonymity was guaranteed, which is why we cannot describe the place and position of our interviewees in detail and why all names in this text are pseudonyms. Interviewees were also promised that they would have the possibility to check any quotes we wanted to use prior of publication.

Qualitative data are collected selectively according to the research question (Lincoln and Guba, 1985; Styles, 1993; Spencer, et al., 2003; Yardley, 2000) Yardley (2000) suggests that conducting and analysing qualitative research should be based on four broad principles: 
sensitivity to context; commitment and rigour; transparency and coherence; and impact and importance. The study reported in this paper has followed these requirements. These have been interpreted in the following ways: sensitivity to context requires an awareness of the milieu, knowledge of the policy context, a rapport-building and empathetic interview style; commitment and rigour, requires thorough and systematic attention to the participants' accounts and analyses that strive to be honest, accurate and complete; transparency and coherence refers to a thorough explanation of all research steps to both the participants and the ultimate reader; impact and importance, strives to produce outputs which are meaningful.

Our study is situated at the crossroads of several research areas. Although we are interested in work and workers, trade unions and the relationship between jobs and the environment, it is not our intention to test macro-economic issues such as those represented by the Porter hypothesis. Our focus is trade union strategies towards climate change and the ways in which they are reflected upon and conceptualised by unionists in order to integrate them into the trade union agenda. Whatever researchers predict, for changes to happen, those directly engaged with environmentally damaging production need to become the agents of change. Our interviewees were high-level trade union officials whose portfolio was 'the environment'. In many cases this had meant that the traditional trade union issue of health and safety had been broadened to include climate change. Their views did not represent the general view of trade unions, nor probably the majority view of the members within the union they represent. However, the climate change policies of their union depend to a high degree on their ability to convince their colleagues and the broader membership of their views. They can be regarded as the opinion leaders on issues of climate change, which is why their positions are worth examining. Trade union policies, like all policies, depend on political conjunctures, including economic, political and social developments. Political changes occur only when different developments point in the same direction, and the role of individuals is one decisive factor in such a conjuncture. Without individuals having the necessary knowledge, determination, and capability a political conjuncture enabling change will not be realised. The subjectivity of social actors, especially those in positions where they can initiate change counts: "Measurable or not, subjectivity is itself a fact, an essential ingredient of our humanity. Rather than excluding it from our field of observation because it is too difficult to handle, we need to seek methods and guidelines for its use and interpretation." (Portelli, 1997:82) As Portelli further argues, the importance of subjective experiences and representations lies in the range of "possibilities" they make available. "On the plane of content it (the representative quality of oral sources) is measured less by the reconstruction of the average experience, than by the subjective projection of imaginable experience: less by what materially happens to people, than by what people imagine or know might happen." (Portelli 1997: 86). Since our interviewees occupied influential positions, what we can learn from their responses, represents not the average position of trade unionists but a range of possible positions among unionists on climate change today. They enable us to understand in which directions trade union environmental policies might be developing.

We have employed discourse analysis, defining discourses in the Foucauldian sense as a specific way in which issues are articulated, using certain concepts that are accepted or challenged, speaking from a specific social position, which define what can be said and how, 
and also what needs to be avoided (Foucault, 1970). Thus, when analysing the statements of our informants we look for connections to societal understandings of the issues they raise. We have striven to understand how our informants use, make sense of, and transform the concepts and arguments which are available within society to make them work within their own individual and professional context. While we aim to understand why certain argumentations are useful for those articulating them we also want to show the contradictions within those discourses.

Although Trade Union documents were studied, for this paper we have prioritised the information we obtained through interviews as they provide more detailed and nuanced accounts of the various positions. In published documentation the conflicts within and between unions are understandably minimised for the sake of consensus. Our interviewees explained the difficulties and contradictions of designing environmental policies in the unions, which enables a better understanding of how policies are engineered. For this paper we have selected the quotes, which represent the four discourses we found in analysing the material in the clearest way.

\section{Jobs vs. Environment - discourses challenging the dilemma}

Trade unions have been described from a philosophical point of view as part of the "ideological state apparatus" (Althusser, 1977), from an economic point of view as "third sector" organisations (Adaman and Yahya, 2002; Chasse 1995; Valentinov, 2008), from a political perspective as one of the three "social partners" (with governments and business) (Taylor and Mathers, 2002; Pochet, 2002; Ferner and Hyman, 1998) or as social movements (Gajewska, 2008). In our view, unions can embody any or all of the functions implied in such definitions, depending upon time and place. They can create identities and organise campaigns as social movements (Rucht, 1999), become corporate partners of management, take part in negotiations with government and business, or cooperate with environmental organisations, becoming part of new social movements (Scipes 1992; Tattersall, 2010; Moody, 1997).

Hyman (2001) has argued that the debates of the $19^{\text {th }}$ century saw the creation of three trade union identities. They are not mutually exclusive but they serve to highlight different perspectives that might account for different trade union approaches today. The first model revolved around unionism as anti-capitalism in which the priority was to advance workers' class interests though 'militancy and socio-political mobilisation' (p2). The second saw trade unionism as a means of creating social integration. Evolutionary reform rather than revolutionary transformation was the modus operandi demanding that social needs rather than private profit should be the goal of industry. The third, 'business unionism', is most familiar in the UK and the USA. In this, the priority for trade unions is collective bargaining and the representation and protection of occupational (rather than class or societal) interests.

We would suggest that 'business unionism' can also be found in countries like Sweden and Germany. In Sweden, unions are proud of their success in negotiating high salaries and good working conditions in cooperation with business and governments 
(Elevander, 2002). Where business unionism is predominant, the interest in environmental issues is less likely to develop, since efforts are concentrated on workers' interests at the workplace, and less on their interests as citizens outside the workplace. At their workplaces workers are not citizens in the true sense of the word, since they do not have any legalised say in a company's decision making.

One of our informants claimed that a neglect of environmental concerns is historically new for unions:

Rainer: "It's quite interesting, because if you look back in history, trade unions were some of the first environmentalists. We were the first ones that made the link between the workplace and the local community. So when you look back in the industrial revolution it was the trade unions that were saying, 'Hang on a minute, these rivers are polluted, and our families are getting sick.'"

Rainer is referring to the early days when unions created "organizations to advocate and develop gender equality, consumers' interests (the cooperative movement), popular health and welfare, housing, culture in all its aspects, education, leisure activities, and human rights (including anti-colonial movements)" (Gallin, 2000:4). Re-connecting to this tradition paves the way for unions to engage in climate change policies:

Rainer: "And I think what the whole debate in Copenhagen and this process is doing is meaning that the trade unions really are having to redevelop the role that they used to have, that we need to take a much louder position on this whole issue."

Rainer's suggestion can be understood within a theoretical framework that has not been prominent within unions to date. Hyman's model compares "business unionism" with a "social needs" unionism but neither considers 'nature' as a trade union concern. All three models commit the error that Marx pointed out in his 1875 critique of the Gotha Programme of the German Socialist Party, which claimed that labour is the source of all wealth: "Labor is not the source of all wealth. Nature is just as much the source of use values (...) as labor, which itself is only the manifestation of a force of nature, human labor power." (Marx, 1983). Defining work, Marx emphasized the essential role of nature: "The worker can create nothing without nature, without the sensuous external world." (Marx, 1988:72, emphasis in original). In the course of labour movement history, the connection between nature and labour has rarely been made. One reason being that natural resources used in production are privately owned and have therefore been considered outside the reach of workers' control.

Analysing our material we asked whether and how our interviewees conceptualised the relationship between nature and labour. Most of the time this was not the case and in our conclusion we discuss the consequences of this. The following sections identify four discourses used by unionists, ranging from improving technology to creating a new global democracy, to describe what needs to be changed for climate change measures to be effective without compromising workers' interests. 


\subsection{There is no conflict - the "technological fix" perspective}

Some of our interviewees did not think there was a conflict between protecting jobs and protecting the environment.

Rainer: "You have to ask yourself, for a worker to feel there's a link between climate change and losing his job, that doesn't suddenly spring into someone's mind - it comes from somewhere. And the question is where does that message come from? So I think the role of the international or the national unions is actually to put forward the alternative view which says: 'Hang on, this is not about you keeping or losing your job, this is about developing industries and developing the company.'

So what our role is - and this is how it links very closely with the South - is we need to make sure that there is the best available technology in new plants that open in developing countries. We also need to make sure that there is a technology transfer between plants in the North and the South. There was a report that was produced by the International Energy Agency, which was key on steel, which said that if you took the best technology there is today and you replicated that through every plant in the world, you would reduce the emissions from the steel producers by over 50."

The perspective Rainer offers represents a view discussed above, namely that a low carbon economy can be realised through economic growth. Technological innovation appears as a solution that combines the best of both worlds: it protects an industry by modernising it and protects the environment by reducing emissions. However, as a representative of an international union, Rainer's perspective cannot only be oriented towards the North. The technological transfer from the North to the South is a demand coming from unions of the Global South that now forms part of the climate change policies of the ITUC (2011). Almost invisible within the unthreatening discourse of a "technological fix" lies a critique of the privatisation of innovation and patents. Rainer himself highlights a contradiction in the tech-fix solution:

"The other reality is you've often seen a steel plant that would employ at one time 20,000 people would now employ 3,000 and produce the same amount of steel. So the production process has changed. And that's part of the natural evolution."

Even when reducing emissions does not imply closing down workplaces but renewing their technology, this still means that jobs will be lost due to the higher productivity achieved through better technology. The technological solution does not solve the conflict between environmental protection and job protection. Redundancies could only be avoided by increasing production levels which would increase emissions again.

Rainer describes redundancies through technological innovation as a "natural evolution." Describing something as natural connotes in everyday understanding inevitability, the impossibility of human intervention into such a process. This 'naturalisation' of a social processes obscures an alternative: redundancies as a result of technological innovation would not be necessary if working hours were to be reduced, which would lead to the triple dividend identified earlier (Schor, 2010). This argument is rarely put forward because from the point of view workers reducing working hours is 
impossible if it is accompanied by a corresponding reduction of salaries. From the point of view of capital, a reduction of working hours without salary cuts also appears impossible, since it would reduce profit margins.

\subsection{Beyond the technological fix: social transformation}

The example above shows that technological changes are not socially neutral. If workers are not to become the victims of technological change, technological and social transformations need to go hand in hand. Julio, responsible for environmental policies in a European union, argues.

Julio: "For example, the social problem of (...) road transport - it's not easy. The position of the driver is a real position in society. When you are a driver, you do not have a high qualification but you have a real job - and you have real recognition. (...) You have a real identification. Because when you are a (...) young boy, you play with a car, and you hope to become a driver. (...) It's not a technical problem. We know the technical problem perfectly well now. (...) We need to change the social image and the population.

Julio is arguing that most workers see the content of their work as a central part of their life. They aim to do "a job well for its own sake" (Sennett, 2008: 9). Work is articulated with a specific way of being in the world; it gives people a sense of purpose and implies a specific 'way of life': adventure and independence in the case of the driver. Apart from the satisfaction derived from work, jobs also provide, what Julio calls a "position in society", reminding us that identities are not merely individual. Each kind of work provides a social subject position in the context of power relations. The lorry driver connotes a specific masculinity associated with a certain technology (a heavy truck). it signifies individuality and independence, and capabilities. These imagined qualities are relational: they make sense in opposition to images of a femininity, regarded as estranged from technology, situated in the house, caring for family members. They also acquire meaning in relation to other forms of masculinity, like office workers, who, from the point of view of manual workers, appear as "pushing paper" (Connell and Messerschmidt, 2005; Willis, 1977; Tracy and Scott, 2006; Collinson, 1992).

Working life creates an abundance of social relations and workers position themselves within these relations, developing identities invested with a feeling of autonomy and power, depending on the labour process within which they act (Haslam, Reicher and Platow, 2010). Transition programmes in the past have predominantly focused on retraining workers for new professions in new areas. They usually don't take into account that work is an important anchoring place of people's identities. Therefore, in addition to possible material insecurities changing jobs also threatens people's identities (Breakwell, 1986). Campaigns for "green jobs", if they are to be successful, need to consider how envisaged new jobs will challenge collective representations of work, images of masculinity/femininity, manual/mental work, of worthwhile and empowering jobs. This connects with Elizabeth Shove's argument made in the context of changing consumption. She argues that consumption practices are embedded in particular technologies and images. For instance, taking a shower holds connotations of freshness, becoming revitalised, being clean, and being modern (Shove, 2003). Considering work identities, it becomes clear that 
campaigns labelling coal, steel, or chemical industries as "dirty" can serve to alienate workers in those sectors from climate change measures, since they feel their identities and pride as workers are threatened. The next section will look into the ways in which workers' identities are taken into account when unionists discuss among each other how a lower carbon production can be achieved.

\subsection{The legitimacy of immediate interests: when workers talk to each other instead of being talked to}

Since different parts of the economy have different impacts on climate change, the positions of unions differ according to the sectors in which they are organising workers. In the transport workers' union, which organises road, maritime and aviation transport workers across the public and private sectors, the conflict between jobs and environment translates into tensions between members of different sectors. Public transport workers (i.e. rail and busses) are more in favour of environmental policies, while road and aviation workers are more reluctant. As Sara from the ETF explained, "Transport is in Europe the single sector where $\mathrm{CO}_{2}$ emissions are still increasing. 25\% of $\mathrm{CO}_{2}$ emissions are coming from transport". The 'Trade Union Vision on Sustainable Transport Project' (ETF, 2008) addresses this issue while simultaneously trying to overcome the frictions between its different groups of members. Like Joel, Sara told us about the identity of the road worker as an independent worker. In internal debates railway workers would say to road transport workers:

Sara: "Is it really in the interest of long-distance freight transport workers to stay away from home two weeks, one week even, when we have a transport system where we say the long distance for inland waterways, rail, and short sea shipping or so? And then you always have the last mile, as it's called, and this will remain road transport. Can't we have a joint vision on this, also from the interest point of view of workers? Is it really in the interest to sleep on the lorry two weeks, going from Sweden to Spain?' And we know that when workers are young it's maybe even... Well, in the past there was this feeling of independence."

The key word here is interest, more precisely workers' interests. Interests are conventionally defined in opposition to values, morality, and ethics. While the latter are seen as guiding principles for all human action (sometimes historicised, sometimes understood ahistorically), interests are usually regarded as dividing a community, as standing in the way of or in contradiction to morality and ethics. Conflicts about climate change politics can be presented as conflicts between different ethics or value systems (Charlesworth \& Okereke, 2010). There is a broad literature looking at the relationship between ethics and climate change (Jamieson 1996). Ethics can also be understood as systems of prescriptions, referring to a common humanity, thereby in danger of obscuring the power relations dividing humanity (Haug, 1993). In contrast, negotiating interests allows for transparency. It enables a discussion about the legitimacy of interests, their relation to each other, and their generalisability. As Fung and Wright (2003) demonstrate in their example of participatory budgeting in Porto Alegre (Brazil) the open discussion of how funding should be distributed across the city made it impossible for the wealthier social groups to claim their interests. They appeared as what they were, the interests of a privileged group that could only be realised at the expense of the legitimate interests of the poorer majority of the city. If generalised, the interests of the wealthy part of the 
population, would have bankrupted the city.

In our transport example, negotiating interests permits a discussion about the relationship between conflicting interests people hold simultaneously (being at home and being independent on the road). In contrast, a debate about the morality of an act can create a smoke screen of generality and abstraction behind which different interests and their questionable legitimacy and origin become invisible.

Instead of presenting their fellow union members with a choice between following their supposedly egocentric interests or acting for the common good (Gardner and Stern, 2002), unionists can engage in a dialogue where the interests of workers are the point of departure, not something to be neglected. Thus, transport workers are asked to re-think what they see as their interests, instead of being asked to abandon or feel guilty about them. Sara's account shows how interests are linked with identities. The feeling of independence constitutes the interests of the workers to drive their trucks. However, people have different, often conflicting identities and thus interests. The transport workers union try to convince their truck driving members by appealing to another set of interests (being with their families), which might be more in tune with the interests of creating a sustainable transport system.

We have dwelt at length on this dialogue between workers seeking to define their different interests in a way that makes them compatible, because such a dialogue provides lessons for negotiating climate issues beyond work and the trade union movement. Such dialogic forms of negotiating interests are in line with demands for a deliberative democracy (Dryzek, 2000; Hendriks, 2006; Hayward, 2008) or with the aims of the Transition Towns movement which seeks to engage communities in transforming their ways of life in their own and societal interests (Hopkins, 2008). The sustainable transport programme developed by the ITF makes a link between environmental working conditions and healthier working conditions, better qualifications, a better quality of life, and more cooperative relationships with fellow workers enabling relations of mutual solidarity instead of competition (ITF, 2010).

\subsection{General interests}

The immediate interests of workers concerning their work and families, however, are not necessarily identical with what some of our informants called 'the general interests of the workers'. The last discourse we discuss is one that aims to define such a general interest.

Julio: "(...) for the trade unions the priority is to defend employees, to defend the working conditions, but also to defend the general interest. And the debate inside about the general interest - the resolution of the debate is very interesting. For example when I arrived here six years ago, I asked immediately to have this portfolio - it is my priority. And many colleagues were very surprised, because it was not in fashion at that time."

The general interest of workers transcends the defence of their working conditions. 
It is an interest that is not immediately obvious, otherwise there would not be the need for an internal debate. Julio connects such a general interest with his portfolio: health, safety and environmental issues. By making this connection, Julio defines the issues that need to be included when the general interests of workers are to be discussed: "And we have a big discussion about what the general interest is for workers, what does the protection of health and safety mean?" The need to discuss this question arose when some unions in Europe rejected elements of the REACH regulations (EU, 2011) aimed at banning dangerous substances in production. Unions of chemical workers argued REACH would threaten jobs. It was not only the external 'nature' that these unions disregarded, but even the nature of workers, i.e., their bodies. In Julio's view, such a narrow approach was the result of a trade union tradition that did not have "a strategy that is independent from their enterprise." Without an alternative concept of production they believed that defending their members' jobs meant accepting the dangers implied in the existing production. However, broadening the definition of workers' interests implies broadening the unions' strategy to include developing an alternative form of production. Although the trade union campaign for "Green Jobs" and a "Green Economy" points in that direction, it focuses on pressurising industry and government to invest in renewable energies and create new, 'green' industries. As Julio's story demonstrates, what is also needed is a willingness and capacity for unions to see themselves as inventors of alternative forms of production based on the knowledge and skills of their members. Returning to Hyman's models, trade unions engaging in converting production could do this from an evolutionary or an anti-capitalist point of view. However, since company owners and managers claim sole responsibility for defining the goals and process of production, conversion projects easily reach the limits of what can be done within the existing system. (see the Lucas Aerospace conversion programme (1972-76): Wainwright and Elliott (1982); Räthzel, Uzzell, \& Elliott (2010)).

Maria defines the general in different terms:

Maria: "I mean, you have a union like mine, Comisiones Obreras. We come from a fight for democracy in Spain not long ago. So it's a union but it's still kind of a social movement as well and it has a strong belief that we defend the general interest, not only the interest of our members. So for such a union putting sustainable development issues on the agenda could be sometimes, not always, easier."

Maria connects the struggle for democracy with the struggle for sustainable development. For her, the general interest does not only transcend the boundaries of the workplace, but also the boundaries of the union's membership. Another member of Comisiones Obreras (CCOO) in Catalonia described the union's commitment as standing on two legs: the 'sectoral' leg, organizing workers in specific occupational sectors and the 'territorial' leg, organizing for the rights of citizens: education, sustainable transport, health, social services, and the environment. Since workers are affected by all social issues, she argued, they are all of a concern of unions.

If Julio asked for an internal debate within the unions to define the general interests of workers, Maria provides us with a perspective on the social conditions under which this debate could be successful. Following Maria's discourse one would argue that to take environmental issues on board unions need to reinvent themselves as social movements, 
not only responsible for the working conditions of their members, but for their general living conditions as well. It is noteworthy, however, that in a recent book that discusses reconstructing trade unions as social movements (Webster et. al., 2008) environmental issues are not mentioned. When unions act as social movements their goals broaden to include working and living conditions, and the way in which societies are organised to provide workers (and all citizens) with social and political rights. An engagement with social issues, as the history of the trade union movement shows, does not necessarily include an engagement with nature as well.

In the concluding section we want to summarize the four discourses we presented and discuss how they could be linked to a perspective that includes nature as a partner, not just as means to a (human) end.

\section{Conclusion}

We have outlined four discourses in which the conflicting relationship between jobs and environment is conceptualised by unionists. The first, the 'technological fix' discourse argues that improved technology will both safeguard jobs and protect the environment. The problem with this approach is that it does not address the societal context in which technological innovations are embedded. The social effects of technological development, like reduced employment, are naturalised.

The second, the 'social transformation' discourse proposes a comprehensive policy in which environmental protection and societal change are interconnected. Workers' fears of losing their jobs are understood in broader terms, acknowledging that people develop their identities through work and therefore transforming production must take into account socially constructed images of work and professions, including social power relations.

The third discourse might be termed the 'mutual interests' discourse. Its focus is on the legitimacy of workers' immediate interests, and it aims to resolve the contradiction between jobs and environment by entering into a horizontal dialogue with workers about how their immediate interests can be re-defined and reconciled rather than abandoned. It replaces an abstract morality with a focus on interests, cooperation and solidarity.

The fourth discourse can be coined the 'social movement' discourse. It includes workers' immediate interests but places them within a broader notion of 'general interests'. Unions are defined as actors in the production process, whose role is not only to defend jobs but also to question the given forms of production and develop alternatives. It conceptualises unions as representing not only the interests of workers at work, but in society at large. Consequently, as Maria argued, a union defining itself in this way, needs to go beyond defending solely the rights of its members and includes the interest of all those who want a just society. This is what defines "social movement" unionism (Webster et al., 2008). Social movement unionism will claim, as Julio did, the right to decide how production is organised and how decisions in society are taken. One example of this was CCOO who saw its role as taking part in changing societal conditions - a view that is not generally taken by other unions in Europe. 
All these discourses have as their points of departure different definitions of workers' interests, broadening them to encompass society as a whole. Except for the 'technological fix' discourse all of them demand a transformation of the relationships of production and the ways in which societies are organised claiming the necessity for unions to contribute to such a transformation. All four discourses aim to tear down the invisible wall that exists between workers as workers in workplaces and workers as citizens outside their workplaces Thus, they are not mutually exclusive since they all imply a re-invention of unions as social movements, even if this is only articulated explicitly in the last discourse. (Webster et. al. 2008; Burawoy, 2010).

The specificity of the discourses can be explained on the one hand, by the history of the union from which the speakers came and on the other hand by the subject positions which they occupy now. It is not surprising that a representative of an industrial union, in which new technologies are invented and produced, employs the "technological fix" discourse. Julio came from a union which has a tradition of developing alternative models of production, which is why this was central to his argumentation. The discourse departing from the legitimacy of "immediate interests" can be explained in the context of a union that has to constantly negotiate and reconcile the different interests of its members according to the different sectors which it organises. In the case of climate change policies, the union organised members, which had to gain from such policies (e.g. public transport workers) and others, whose jobs would be transformed through them (e.g. truck drivers). When immediate interests can be in line with climate change policies it seems reasonable to search for immediate interests among the membership that would also be brought in tune with such policies. Finally, unions with a tradition to engage in politics were more likely to situate the interests of their members within the general interest of society at large. The reason why all our informants developed a broader vision of union activism and responsibility that did not end at the factory gates, was, we think, due to the fact that they were all representatives of international unions and therefore were not directly confronted with the day-to-day interests of union members. Often distinctions between union officials and rank-and-file members are made by arguing that the former are remote from the real interests of union members. One can also argue, that a certain distance is necessary in order to be able to develop more future oriented perspectives. The question is, however, how can such perspectives be translated into the everyday necessities of union policies at national and local level? Our ongoing research will seek to answer this question. Examples of local unions defending environmental concerns can be found in Burgmann and Burgmann, 1998, Snell and Fairbrother, 2011, Savage and Soron, 2011.

None of the discourses referred to economic macro-models like the Porter hypothesis as a means to strengthen their argumentation. Seeing themselves as social actors changing society's priorities does not require them to rely on models which assume that future perspectives can be deduced by analysing past processes. Such models invariably exclude the possibility of interventions which would change the course of the predicted developments.

Returning to our overarching question concerning the role of nature in trade union discourses, none of these discourses make explicit reference to nature. Unionists did not 
talk about labour and nature as equally necessary sources of wealth. Nature and the environment was conceptualised as something that provides a quality of life, of well-being and health for workers; it was not understood as a partner in the production process. The discourse of interests, even in its broadest sense, reaches its limits when it comes to nature. Interests have to be articulated, defined and fought for by social groups; 'nature' cannot articulate its own interests. Nature is social (Castree and Braun, 2001) in so far as it is perceived and transformed through human practices within historically specific social relations. To speak about "social relations of nature" includes a notion of nature as a partner with its own needs in this relationship (Benton, 1989, O'Connor 1998). Social relations which reduce nature simply as a tool for the realisation of human needs, will destroy not only nature, but human nature as well.

There was one moment during our interviews though, where the term nature was used explicitly by a unionist in South Africa: "So, you know, it's all the concepts about what's happening in the metabolic rift and between nature and humans. The National Treasurer of NUMSA, has written some articles about Environment being a union issue." This sentence opens up a new perspective, namely the relationship between humans and nature. The notion of the 'metabolic rift' refers to Liebig's concept used by Marx (see Foster 2000:147 ff). They argued that the separation of town and country, together with the implementation of monocultures, destroyed the exchange between human nature and nature. In its wake followed what we might call social reductionism in the labour movement, where nature disappears or is reduced simply to a means for meeting human needs, and an ecological reductionism in environmental movements, where humans become a mere threat to nature. As discussed above, it is through labour, i.e., through the transformation of nature, that humans develop their own nature, i.e., their specific capabilities. To recognise this would connect the need to take care for nature in its own right with workers' interests, namely with their identities developed through their work. It might also provide an opportunity through which unionists and thus their members could conceptualise themselves as partners of nature, not as its exploiters. In this sense they could find "common interests" between human nature and nature in creating forms of production that care for the well-being of both. To conceptualise nature as a partner in human development instead of seeing it as a victim, would enable a decisive shift in the existing climate change policies in which the ecology remains subordinated to the economy. 


\section{Acknowledgements}

The project was funded by Forskningsrådet för Arbetsliv och Socialvetenskap (Swedish Council for Working Life and Social Research; FAS) under the title Trade Unions facing the dual challenge of globalising work division and globalising environmental degradation.

We would like to thank the following organisations and trade unions for their cooperation: Labour Research Department (London); Instituto Sindical de Trabajo Ambiente y Salud (ISTAS), SustainLabour (Madrid); UN International Labour Organisation (Geneva); Commission of the European Union (Brussels); Global Union Research Network. UNITE, Community; TUC (UK); IF Metall (Sweden); CUT/CNM; Federação dos Metalúrgicos, Força Sindical (Brazil); Comisiones Obreras (CCOO) (Spain); Malaysian Trade Union Congress; Congrss of South African Trade Unions (COSATU), National Union of Metalworkers of South Africa (NUMSA) (South Africa). European Metalworkers Federation, European Transport Workers Federation, and European Federation of Building and Woodworkers; European Trade Union Confederation, International Trade Union Federation Asia - Pacific; International Metalworkers Federation, International Transport Workers' Federation, International Trade Union Confederation. 


\section{References}

Althusser, L. (1977) 'Ideology and ideological state apparatus'. In: L. Althusser, Lenin and Philosophy and Other Essays. London: New Left Books.

Adaman, F. and Yahya M. (2002) 'Theorizing the 'Third Sphere': A Critique of the Persistence of the 'Economistic Fallacy'. Journal of Economic Issues 36, 4, 1045-1078.

Benton, T. (1989). 'Marxism and Natural Limits'. in New Left Review, 178, 51-81.

Bezdek, R. H., Wendling, R. M., \& Diperna, P. (2008). Environmental protection, the economy, and jobs: national and regional analyses. Journal of Environmental Management, 86, 1, 63-79.

Burgmann, M. and Burgmann, V. (1998). Green Bans, Red Union: Environmental Activism and the New South Wales Builders Labourers' Federation, University of NSW Press, Sydney.

Breakwell, G. M. (1986). Coping with Threatened Identities, London: Methuen.

Bronfenbrenner, K. and Luce, S. (2004). 'The Changing Nature of Corporate Global Restructuring: The Impact of Production Shifts on Jobs in the US, China, and Around the Globe', Research Paper, The US-China. Economic and Security Review Commission.

Burawoy, M. (2010). ‘From Polanyi to Pollyanna: The False Optimism of Global Labor Studies.' Global Labor Studies, 1, 2, 300-313.

Castree, N. and Braun, B. (2001). Social Nature: Theory, Practice, and Politics. Massachusetts, Oxford: Blackwell.

Chasse, J. D. (1995). 'Nonprofit Organizations and the Institutionalist Approach.' Journal of Economic Issues 29, 2, 525-533. 
Charlesworth M. and Okereke, C. (2010). 'Policy Responses to Rapid Climate Change: an epistemological critique of dominant approaches'. In: Global Environment Change, 20, 121-129.

Collinson, D. L. (1992). 'Managing the Shopfloor: Subjectivity, Masculinity and Workplace Culture. Berlin: de Gruyter

Connell, R. W. and J. W. Messerschmidt (2005).' Hegemonic Masculinity: Rethinking the Concept. Gender \& Society, 19, 829-859.

DEFRA (2008). A Framework for Pro-environmental behaviours: London: Defra

Dryzek, J. (2000). Deliberative democracy and beyond: Liberals, critics, contestations. Oxford: Oxford University Press.

Elvander, N. (2002). The Labour Market Regimes in the Nordic Countries: A Comparative Analysis. Scandinavian Political Studies, 25, 117-137

ETF (European Transport Workers' Federation) (2008). TRade Union Vision on Sustainable Transport (TRUST). (http://www.itfglobal.org/etf/trust-brochures.cfm accessed June 2, 2010).

EU (2011). Reach: the European Community Regulation on chemicals and their safe use, (ec.europa.eu/environment/chemicals/reach/reach intro.htm, accessed $12^{\text {th }}$ June 2011) Ferner, A. \& Hyman, R., (1998). Changing Industrial Relations in Europe. Oxford: Blackwell. Foster, J.B. (2000) Marx's Ecology. Materialism and Nature. New York. Monthly Review Press.

Foucault, M. (1970). 'The order of discourse' in: R. Young (ed.) Untying the text: a poststructuralist reader pp. 48-78. Boston: Routledge and Kegan Paul, 1981.

Fung, A., Wright, E.O. (2003). Deepening Democracy: institutional innovations in empowered participatory governance. London: Verso. 
Gajewska, K. (2008). 'The Emergence of a European Labour Protest Movement?' European Journal of Industrial Relations. 14, 1, 104-121.

Gallin, D (2000). Trade Unions and NGOs: A Necessary Partnership for Social Development. Civil Society and Social Movements Programme Paper Number 1 June 2000. United Nations Research Institute for Social Development.

(http://www.nfi.at/index.php?option=com content\&task=view\&id=3\&ltemid=9 accessed 10 May 2010).

Gardner, G. T. and Stern, P. C. (2002). Environmental Problems and Human Behaviour (2nd edition). Boston, MA: Pearson.

Goodstein, E. S. (1999). The Trade Off Myth: Fact and Fiction about Jobs and the Environment. Washington, DC: Island Press.

Haslam, S.A., Reicher, S.D. and Platow, M.J. (2010). The New Psychology of Leadership: Identity, Influence and Power, London: Psychology Press

Haug, W.F. (1993). Elemente einer Theorie des Ideologischen. Berlin/Hamburg: Argument Verlag.

Hayward, B. (2008). Let's talk about the weather: Decentering democratic debate about climate change. Hypatia, 23, 3, 79-98.

Hendriks, C. M. (2006). 'Integrated Deliberation: Reconciling Civil Society's Dual Role in Deliberative Democracy.' Political Studies, 54, 486-508.

Hopkins, R. (2008). The Transition Handbook: From oil dependency to local resilience, Dartington: Green Books.

Hyman, R. (2001). Understanding European Trade Unionism: Between Market, Class and Society. London: Sage 
ITF (2010). Workers' rights and Sustainable Mobility,

(http://www.itfglobal.org/education/climatechange.cfm, accessed 16 June 2011).

ITUC (2011). Climate change (http://www.ituc-csi.org/climate-change.html, accessed $12^{\text {th }}$ July 2011)

Jackson, T. (2009). Prosperity without Growth? The transition to a Sustainable Economy. London: Earthscan

Jamieson, D., (1996). Ethics and intentional climate change. Climatic Change 33 (3): 323-336

Keil, R. (1994). 'Green work alliances: The political economy of social ecology'. Studies in Political Economy 44:7-38.

Labor Studies Journal (2011). Special issue on trade unions and climate change, 36, 1, 2011. Lincoln, Y.S. and Guba, E.G. (1985). Naturalistic Inquiry. London: Sage.

Malm, A. (2011). 'China as Chimney of the World: The Environmental Kuznets Curve in Reverse', paper presented at the Workshop on 'Climate change and union activism', Labour Movement Archives and Library, Stockholm, 10 February 2011 Marx, K (1988). Economic-Philosophical Manuscripts of 1844. Translation Milligan, M. New York: Prometheus Books.

Marx, K. (1983). Critique of the Gotha Program (1875). International Publishers edition. Mol, A.P.J., Sonnenfeld, D.A., and Spaargaren, G., (eds.) (2009). The Ecological Modernisation Reader: Environmental Reform in Theory and Practice, London and New York, Routledge.

Moody, K. (1997). Workers in a Lean World. London: Verso Morgenstern, R.D., Pizer, W.A. \& Shih, J-S, (2002). "Jobs Versus the Environment: An Industry-Level Perspective," Journal of Environmental Economics and Management, $43,3,412-436$. 
Neale, J. (2010). One Million Jobs: Solving the economic and environmental crisis, London Campaign Against Climate Change

O’Connor, J. (1998). Natural Causes: Essays in ecological Marxism. New York: The Guildford Press.

O'Grady, F. (2010). Opening Speech, TUC Green Growth Conference $11^{\text {th }}$ October, 2010 (http://www.ituc-csi.org/climate-change.html, accessed $12^{\text {th }}$ June 2011)

Pochet, P. (2002). Social Pacts in Europe: New Dynamics. Brussels: ETUI

Pollin, R.; J. Heintz; H. Garrett, Peltier (2009). The Economic Benefits of Investing in Clean Energy: How the Economic Stimulus Program and New Legislation Can Boost U.S. Economic Growth and Employment. Amherst, MA: Political Economy Research Institute, and Washington, DC: Center for American Progress. (http://www.peri.umass.edu/fileadmin/pdf/other publication types/green econom ics/economic benefits/economic benefits.PDF accessed 10 July 2011)

Portelli, A. (1997). The Battle of Valle Giulia. Madison: Wisconsin University Press.

Porter, M. E. and van der Linde, C. (1995). Toward a new conception of the environmentcompetitiveness relationship. Journal of Economic Perspectives, 9, 4, 97-118.

Rucht, D. (1999). 'The Transnationalization of Social Movements: Trends, Causes, Problems', in D. della Porta, H. Kriesi and D. Rucht (eds) Social Movements in a Globalizing World, pp. 206-22. New York: St Martin's Press.

Räthzel, N., Uzzell, D. and Elliott, D. (2010). 'Can trade unions become environmental innovators?', Soundings, 46, $76-87$

Redclift, M. R., and Woodgate, G., (2005). New Developments in Environmental Sociology, Cheltenham, Edward Elgar. 
Rennings, K., Ziegler, A. and Zwick, T. (2001) Employment Changes in Environmentally Innovative Firms. Discussion Paper No.01-46, Zentrum für Europäische Wirtschaftsforschung GmbH. (tp://ftp.zew.de/pub/zew-docs/dp/dp0146.pdf. accessed 12 July 2011)

Rosewicz, B. (1990). 'Americans Are Willing to Sacrifice to Reduce Pollution, They Say, Wall Street Journal, April 20 (1990).

Savage, L. and Soron, D. (2011). Organized Labor, Nuclear Power, and Environmental Justice: A Comparative Analysis of the Canadian and U.S. Labor Movements. Labor Studies Journal, 36 1, 37-57.

Scipes, K. (1992). 'Understanding the New Labor Movements in the 'Third World': The Emergence of Social Movement Unionism', Critical Sociology, 19, 2, 81-101

Schor, J. (2010). Plenitude: The New Economics of True Wealth, New York: The Penguin Press.

Sennett, R. (2008). The Craftsman. London, New York: Penguin Books.

Shove, E. (2003). Comfort, Cleanliness and Convenience: The Social Organization of Normality. London: Berg Publishers.

Silver, B. (2003). Forces of Labor. Cambridge: Cambridge University Press.

Snell, D. and Fairbrother, P. (2011). Toward a Theory of Union Environmental Politics. Unions and Climate Change in Australia. Labor Studies Journal, 36 1, 83-103.

Spencer, L. Ritchie, J, Lewis, J. and Dillon, L. (2003). Quality in Qualitative Evaluation: framework for assessing research evidence, London: Cabinet Office, UK Government. (http://webarchive.nationalarchives.gov.uk/+/http://www.cabinetoffice.gov.uk/strat egy/downloads/su/qual/downloads/qqe rep.pdf accessed 12 July 2010) 
Stevis, D. (2011). 'Unions and the Environment: Pathways to Global Labor

Environmentalism'. Working USA, The Journal of Labor and Society. 14, 2, 145-159.

Styles, W.B. (1993). Quality Control in Qualitative Research. Clinical Psychology Review, 13, 593-618.

SustainLabour/ITUC (2009). Green Jobs and Women Workers. Employment, Equity, Equality. (http://www.sustainlabour.org/index.php?option=com content\&task=view\&id=551 \&Itemid $=255$ accessed 12 July 2010)

Taylor, G. and A. Mathers (2002). 'Social Partner or Social Movement? European Integration and Trade Union Renewal'. Labor Studies Journal. 27,1, 93 -108.

Tattersall, A. (2010). Power and Coalition. Ithaca, NY: Cornell University Press

Tracy, S. and Scott, C. (2006). Sexuality, Masculinity, and Taint Management Among Firefighters and Correctional Officers. Management, Communication Quarterly, 20, 1, 6-38.

United Nations (2009). Agenda 21, Social and Economic Dimensions: Strengthening the Role of Workers \& their Trade Unions, Section III, Chapter 29, in United Nations Department of Economic and Social Affairs: Division for Sustainable Development (http://www.un.org/esa/dsd/agenda21/res agenda21 08.shtml accessed 6 June 2011)

UNEP (2008). Green Jobs: Towards Decent Work in a Sustainable, Low-Carbon World. Report commissioned and funded by UNEP, as part of the joint UNEP, ILO, IOE, ITUC Green Jobs Initiative. Produced by Worldwatch Institute, with technical assistance from: Cornell University Global Labor Institute.

UNEP (2006). Final Resolution of The Trade Union Assembly on Labour and the Environment, Nairobi, Kenya, 15 - 17 January, 2006 
(http://www.unep.org/labour environment/publications/index.asp accessed July 10, 2011)

Valentinov, V. (2008). 'The Economics of Nonprofit Organization: in Search of an Integrative Theory.' Journal of Economic Issues, 42, 3, 745-761.

Valenduc, G. (2001). Trade unions as agents of environmental awareness: outcomes from the RISE project. In: Hildebrandt, E. Lorentzen, B. Schmidt, E. (Eds.) Towards a Sustainable Worklife. Hans Böckler Stiftung - Edition Sigma, Berlin, 2001, 55-66.

Wagner, M. (2004). 'The Porter Hypothesis Revisited: A Literature Review of Theoretical Models and Empirical Tests,' Public Economics 0407014, EconWPA. (Downloadable at (http://129.3.20.41/eps/pe/papers/0407/0407014.pdf accessed 5 June 2011)

Wainwright, H., and Elliott, D. (1982). The Lucas Plan. A new trade unionism in the making? London, New York: Allison \& Busby

Webster, E., Lambert, R., Bezuidenhout, A. (2008). Grounding Globalization: Labour in the Age of Insecurity. Oxford: Blackwell.

Willis, P. (1977). Learning to labour. How working class kids get working class jobs. Hampshire: Gower.

Yardley, L. (2000). Dilemmas in Qualitative Research. Psychology and Health, 15, 215-228. 